\title{
Analysis of tectonic fracturing in the Mibladen ore deposit (Upper Moulouya, Morocco) and its impact on the $\mathrm{Pb}-\mathrm{Ba}$ mineralization emplacement
}

Driss Yaagoub ( $\sim$ yaagoub.driss@gmail.com )

Universite Sidi Mohamed Ben Abdellah Faculte des Sciences et Techniques de Fes

\section{Saïd Hinaje}

Université Sidi Mohamed Ben Abdellah Faculté des Sciences et Techniques de Fès

\section{Mohamed El Fartati}

Université Sidi Mohamed Ben Abdellah Faculté des Sciences et Techniques de Fès

\section{Youssef Gharmane}

Université Sidi Mohamed Ben Abdellah Faculté des Sciences et Techniques de Fès

\section{Research Paper}

Keywords: Microtectonic analyses, MVT-type mineralizations, Mibladen ore deposit, Upper 26 Moulouya, Morocco.

Posted Date: February 4th, 2021

DOl: https://doi.org/10.21203/rs.3.rs-178568/v1

License: (9) This work is licensed under a Creative Commons Attribution 4.0 International License. Read Full License

Version of Record: A version of this preprint was published at Rendiconti Lincei. Scienze Fisiche e Naturali on May 5th, 2021. See the published version at https://doi.org/10.1007/s12210-021-00995-1. 


\section{Abstract}

The MVT-type Pb-Ba mineralizations of the Mibladen ore deposit are hosted by Jurassic carbonates as well as Infracenomanian conglomerates and sandstones. The mineral paragenesis is mainly composed of galena and barite with lesser chalcopyrite and pyrite, accompanied by supergene oxidation minerals. This ore deposit is the result of a major epigenetic mineral stage with economic orebodies occuring as replacement of pre-existent carbonate rocks, fillings of karst cavities, interstratal joints, collapse-breccias, fractures and faults. Structural and microtectonic analyses we carried out in this ore deposit, allowed us to highlight two main fracture networks controlling ore deposition within karst cavities and interstratal joints: i) NNW-SSE to NNE-SSW trending tension gashes and normal faults; ii) ENE-WSW to E-W trending reverse faults with strike-slip components and transtensive relay zones. All of these structures are developed under a regional compressional tectonic regime divided into extensional and transtensional episodes ( $\sigma 1-\sigma 2$ and $\sigma 2-\sigma 3$ permutations) with sub-meridian $\sigma 1$ axis and sub-equatorial $\sigma 3$ axis. This compressive tectonic event caused the uplift of Mibladen area and favored the circulation of mineralizing fluids along the NW-SE and ENE-WSW major faults such as Amourou and Aouli Faults, during the Infracenomanian period (Upper Jurassic-Early Cretaceous).

\section{Full Text}

This preprint is available for download as a PDF.

\section{Declarations}

The authors declare no competing interests.

\section{Figures}




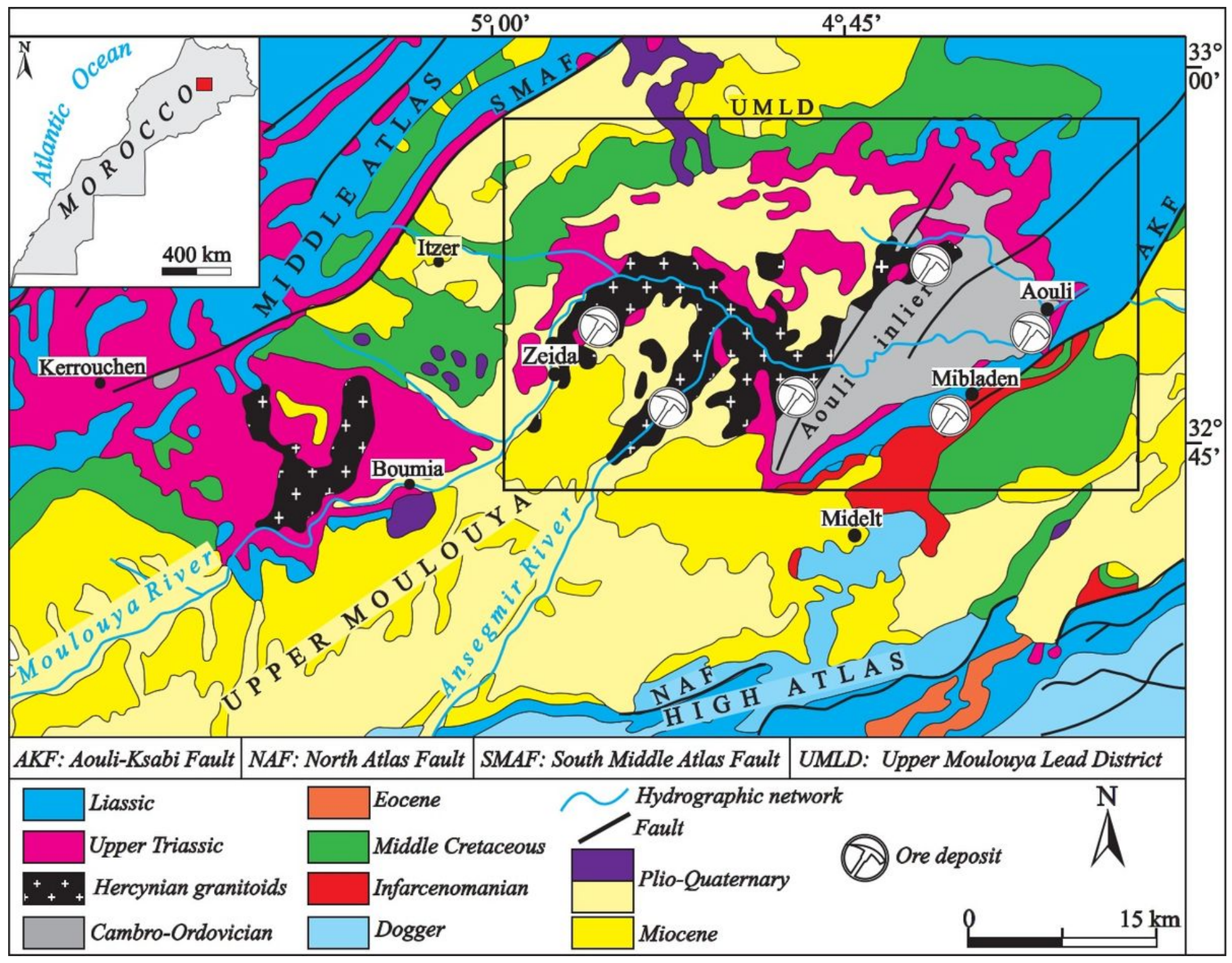

\section{Figure 1}

Location of the Upper Moulouya lead district, modified from the geological map of Morocco at $1 / 1,000,000$ (Hollard et al. 1985). 


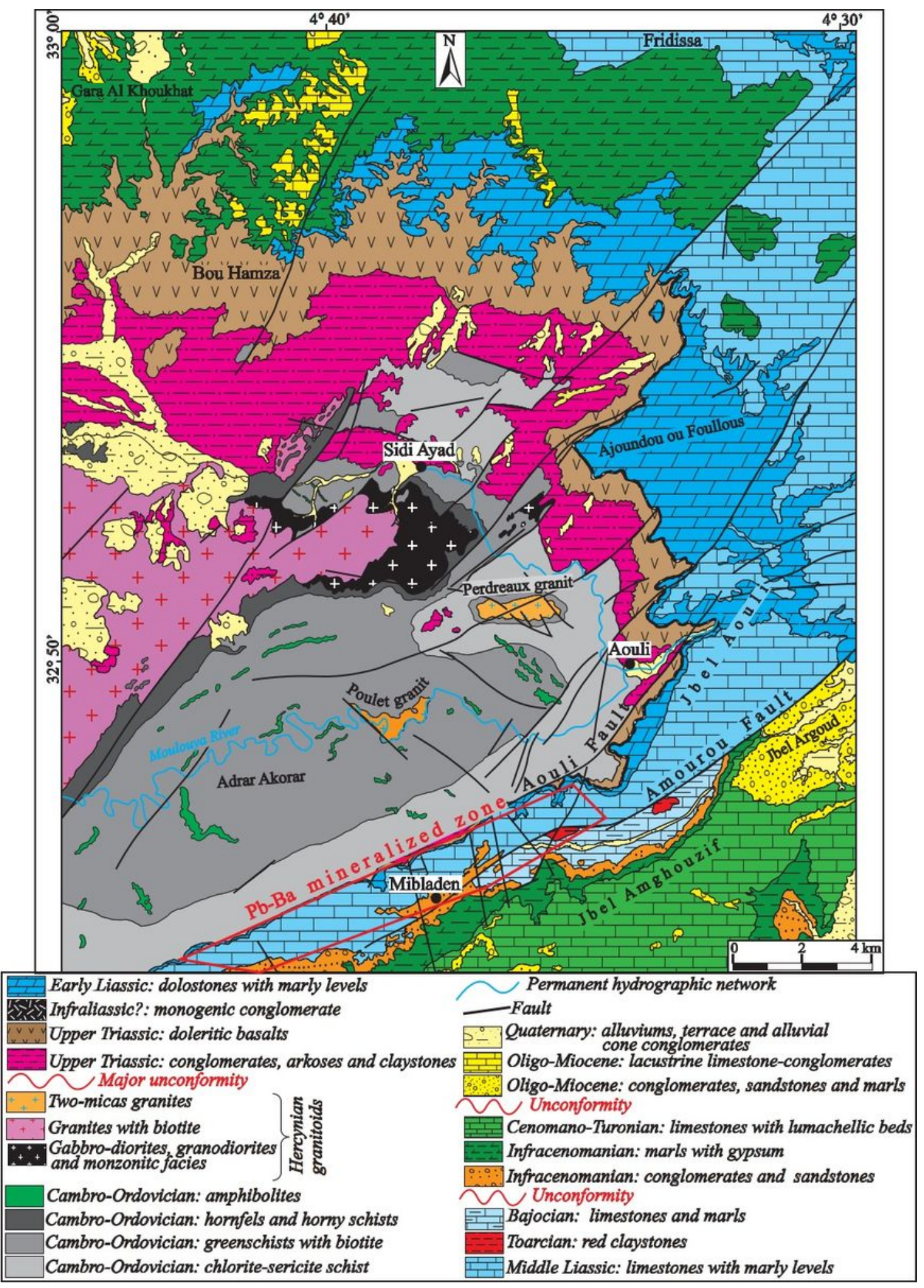

\section{Figure 2}

Geological map of Mibladen (Raddi et al. 2013, modified). 


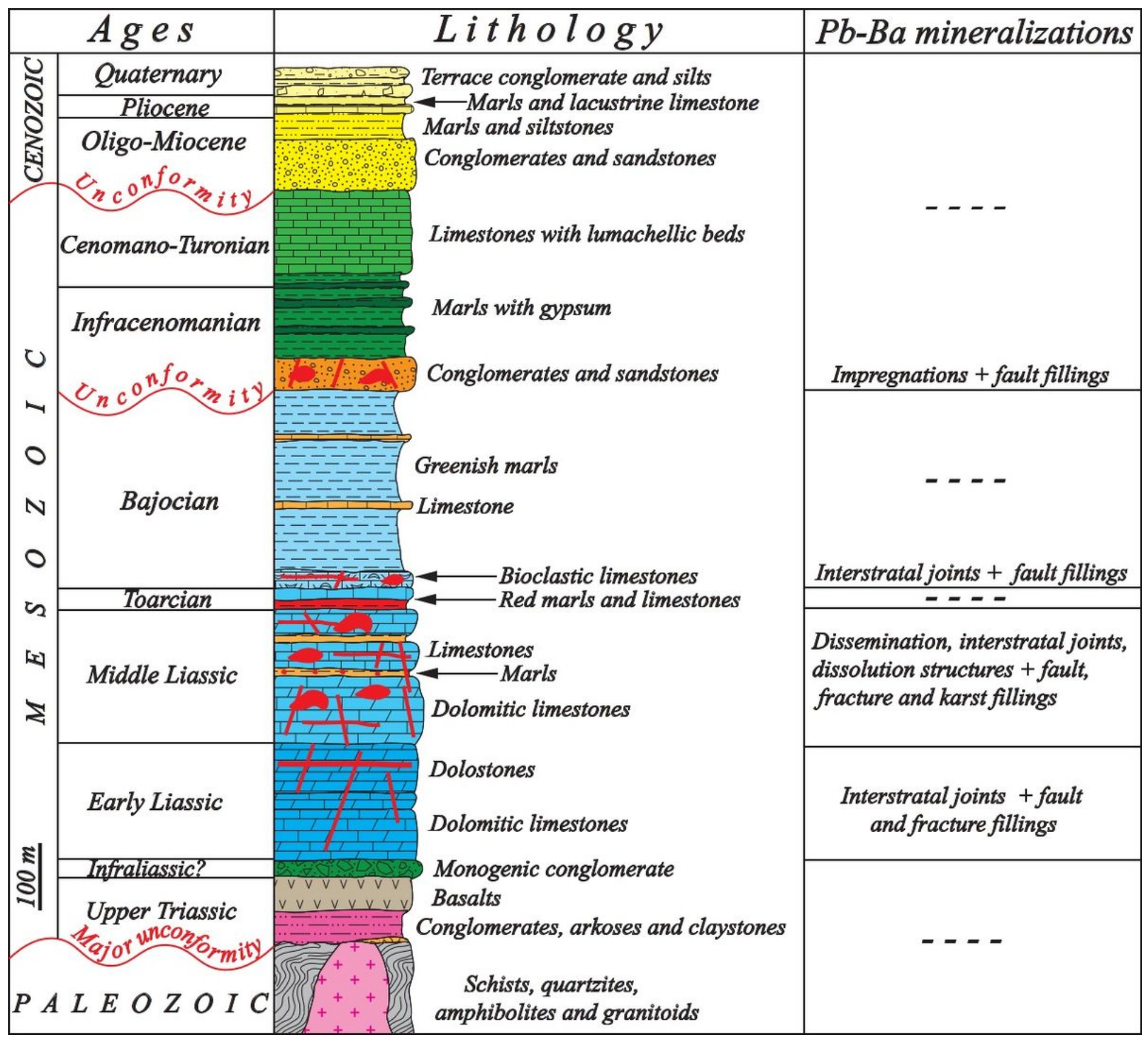

Figure 3

Synthetic lithostratigraphic column of Mibladen with associated $\mathrm{Pb}-\mathrm{Ba}$ mineralizations (Aouli and Zeida mineralizations are not represented here). 


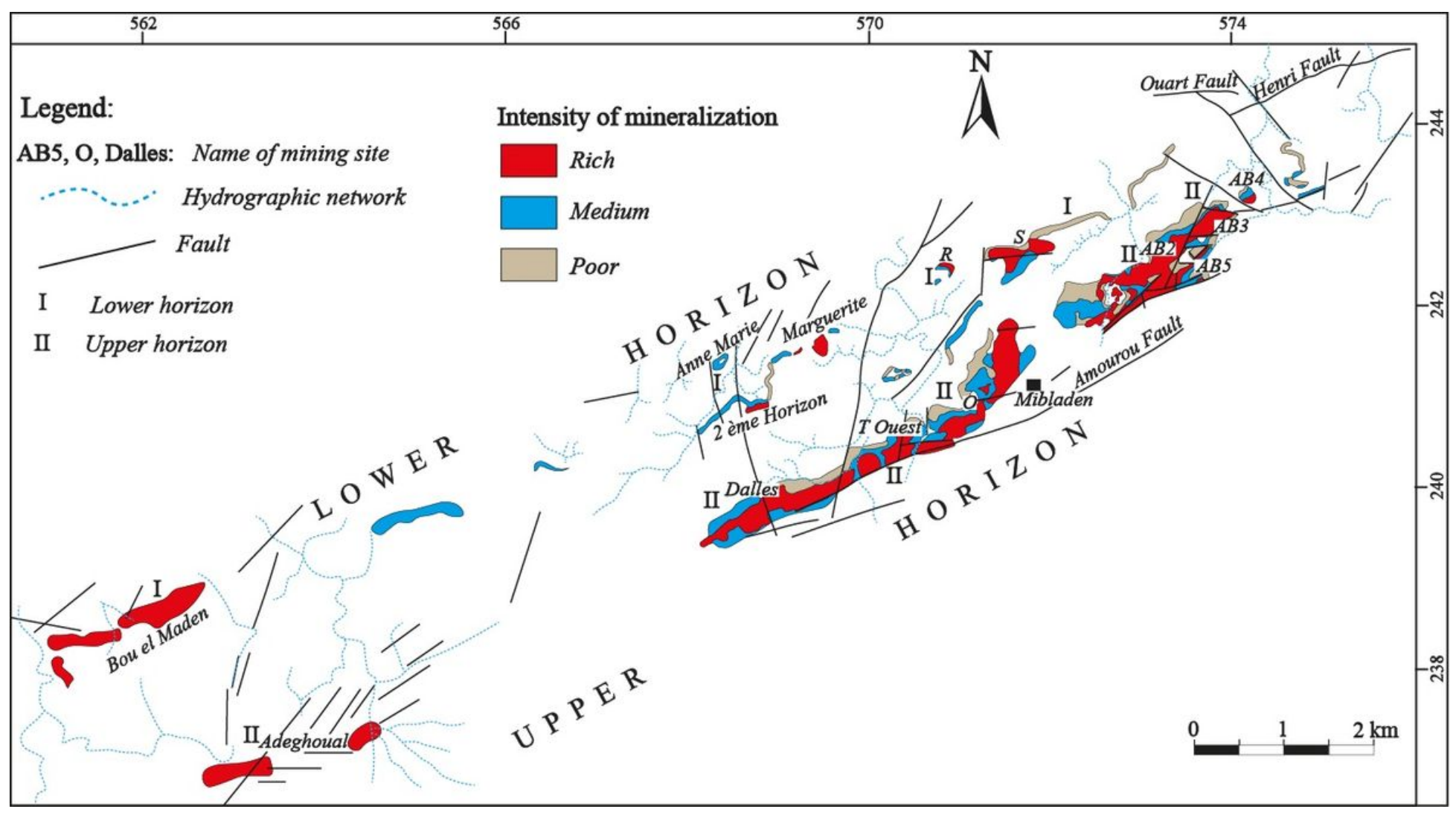

\section{Figure 4}

Spatial distribution of mineralized occurrences in the Mibladen ore deposit (Felenc and Lenoble, 1965, modified). 


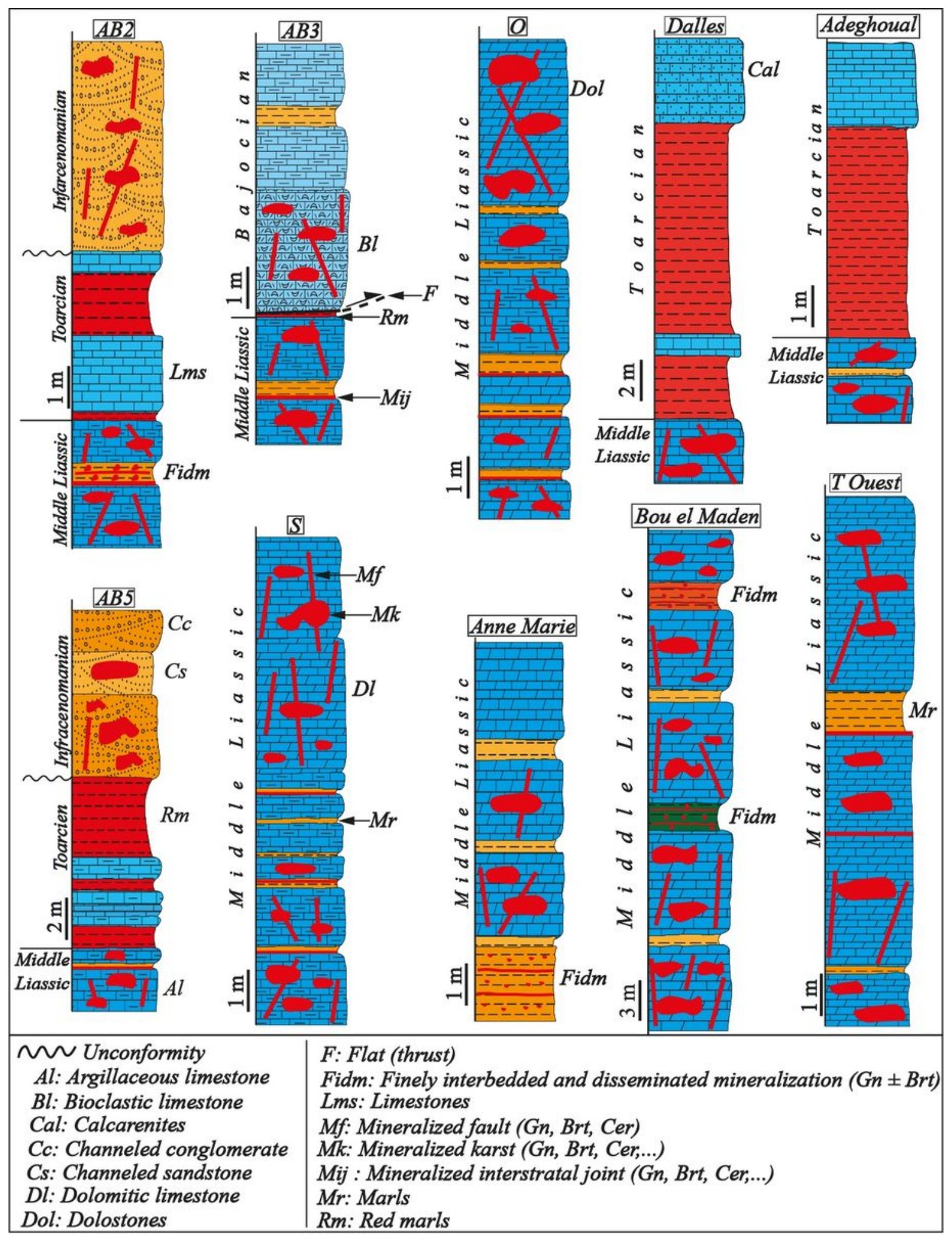

Figure 5

Arrangement of $\mathrm{Pb}-\mathrm{Ba}$ mineralizations within different terms of the Mesozoic series of Mibladen. (Gn: Galena, Brt: Barite, Cer: Cerussite. This is valid for all the following figures). 

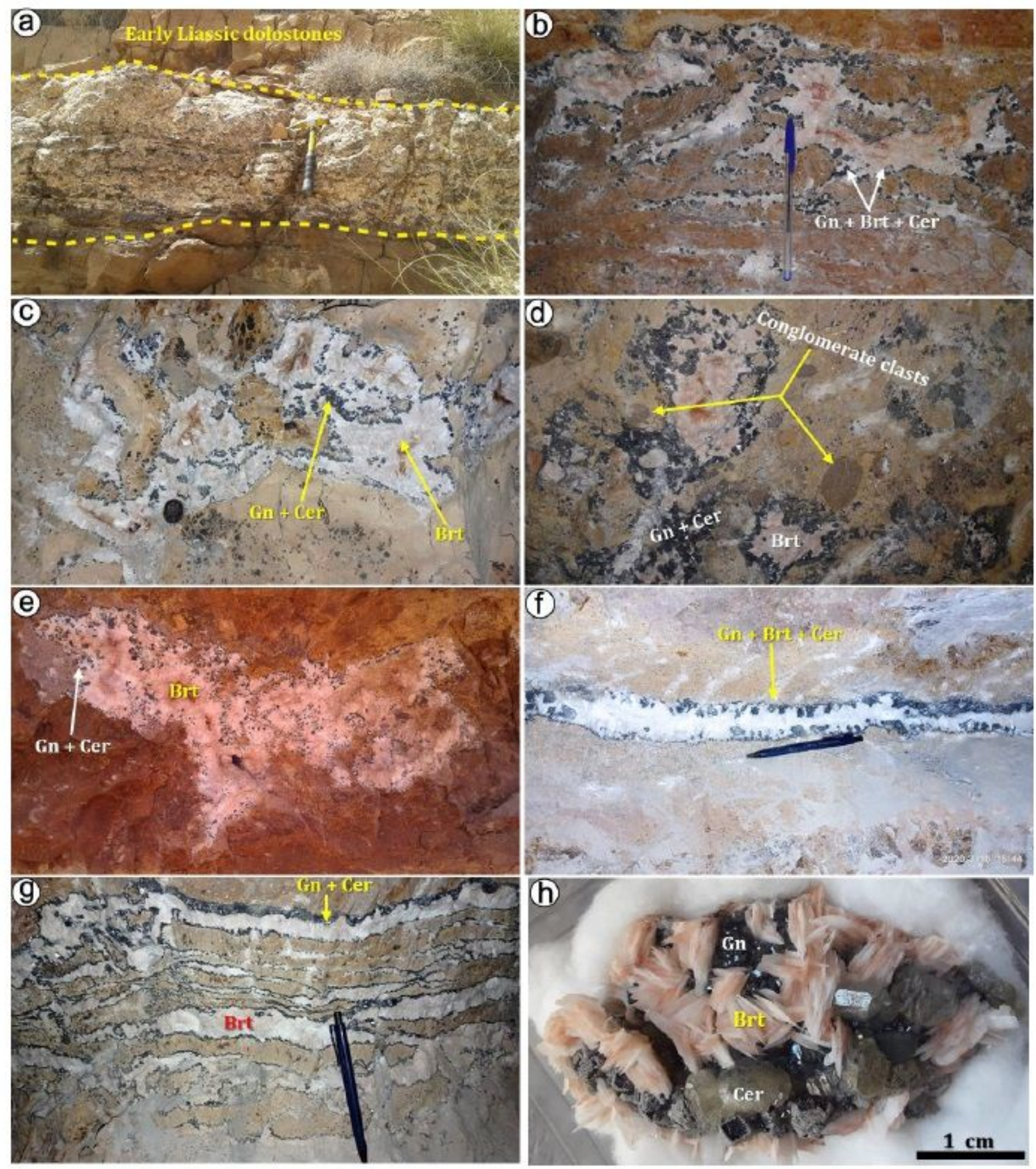

\section{Figure 6}

Gitological characteristics of $\mathrm{Pb}-\mathrm{Ba}$ mineralizations in the Mibladen ore deposit. a) Barite strata interbedded in Early Liassic dolostones. b) Dissolution structures within Middle Liassic dolomitic limestones in the 0 mining site. c) Karst-filling of Middle Liassic limestones in the Dalles mining site. d) Impregnation of Infracenomanian conglomerates in the AB5 mining site. e) Karst-filling of Middle Liassic limestones in the AB2 mining site. f) Interstratal joint-filling in the Dalles mining site. g) Dissolution 
structures within Middle Liassic dolomitic limestones in Marguerite mining site. $h$ ) Mineral paragenesis of T Ouest mining site.

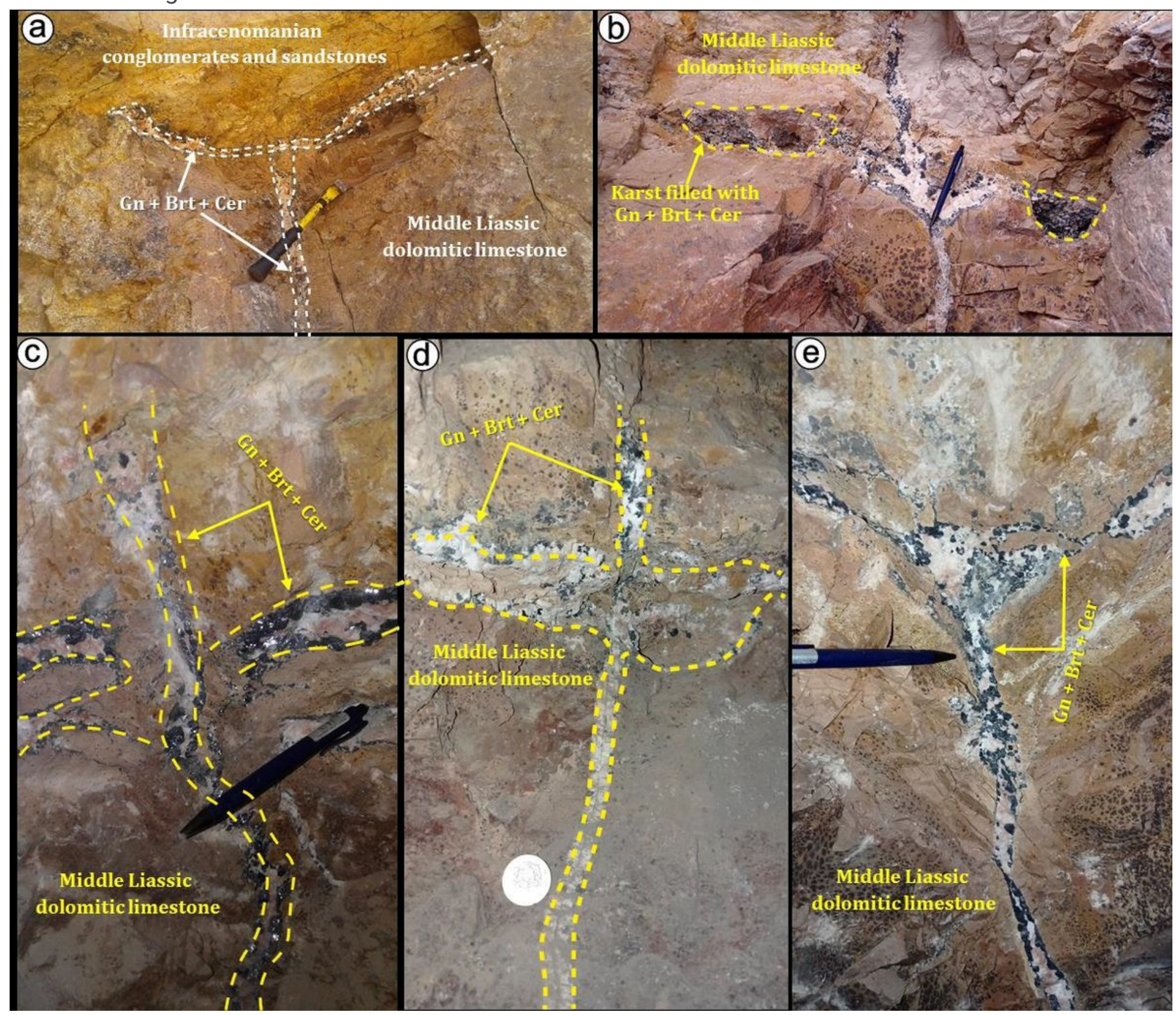

Figure 7

Structural control of $\mathrm{Pb}-\mathrm{Ba}$ mineralizations in the Mibladen ore deposit. a) Fracture responsible for ore deposition in the Middle Liassic-Infracenomanian contact. b) Circulation of metalliferous fluid into a subvertical fracture and its deposition in karstic cavities. $c, d$ and e) Fractures responsible for circulation and deposition of $\mathrm{Pb}$-Ba mineralizations into Liassic interstratal joints. 


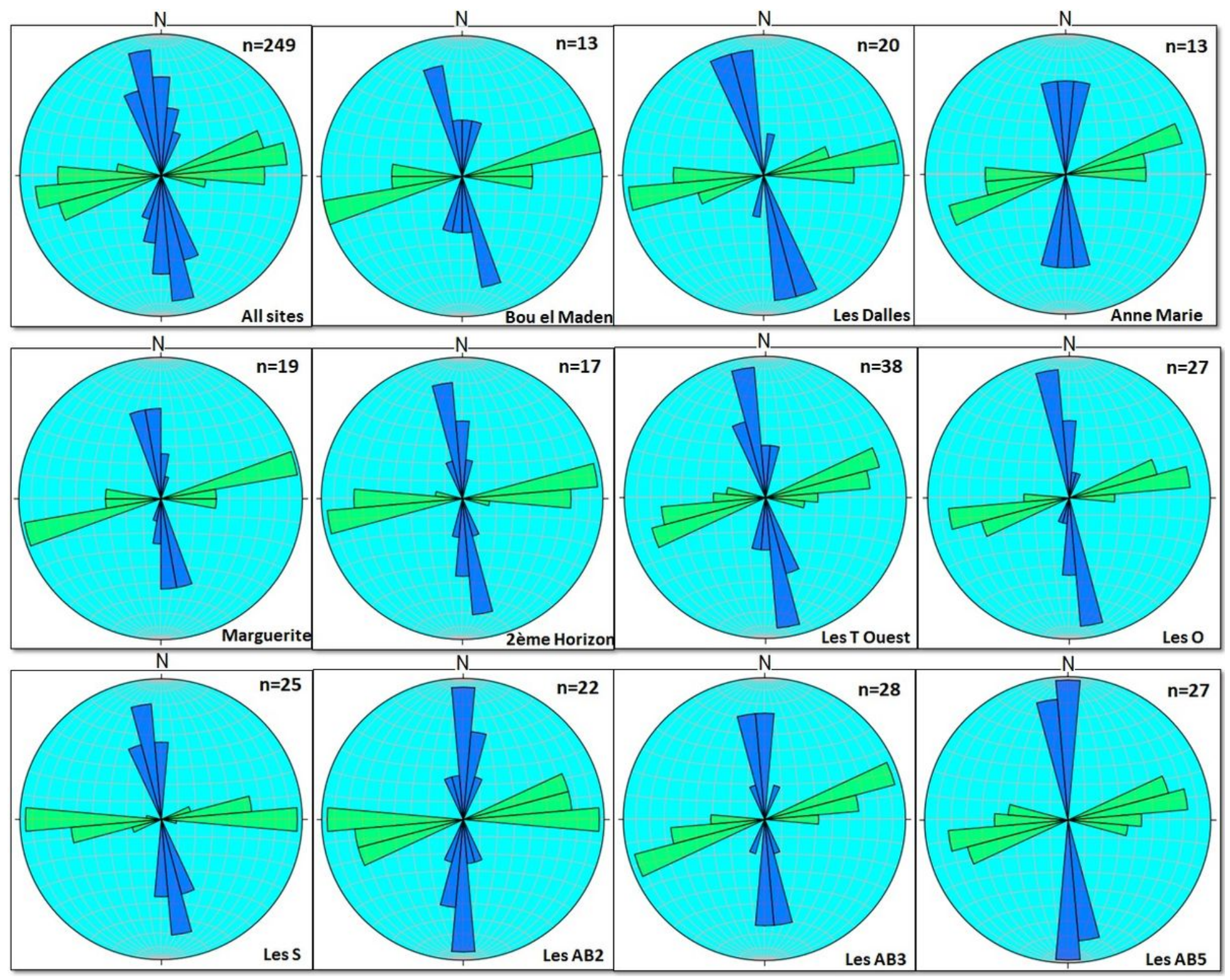

Figure 8

Rose diagrams for mineralized structures in the Mibladen mining sites (green: reverse faults with strikeslip component, blue: tension gashes and normal faults, $n=$ number of measurements. Equal-area stereographic projection, lower hemisphere. See measurement sites in Fig. 4). 


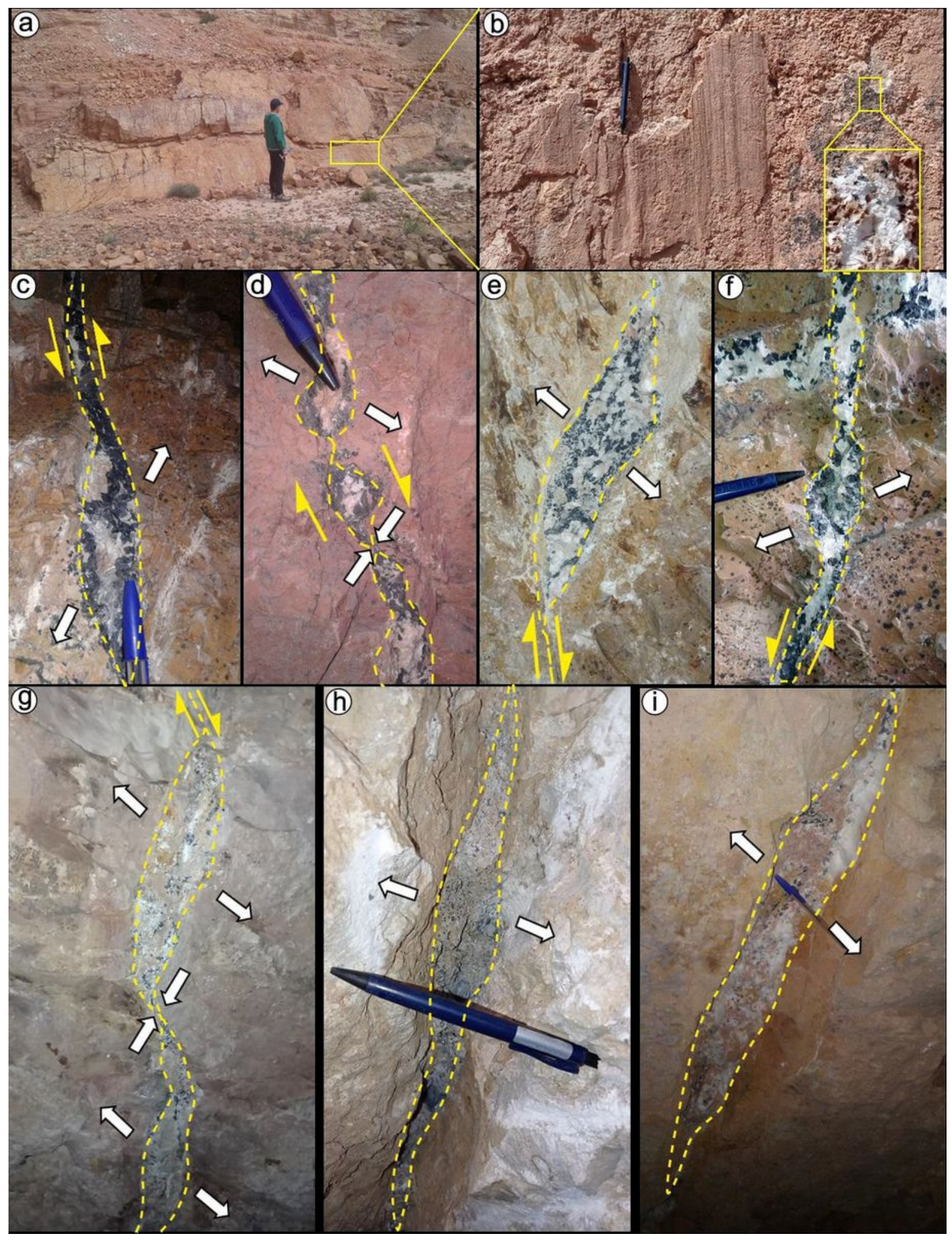

Figure 9

$\mathrm{a}$ and b) ENE-WSW striated reverse fault filled by $\mathrm{Pb}-\mathrm{Ba}$ mineralizations in the $\mathrm{S}$ mining site. $\mathrm{c}$ to $\mathrm{g}$ ) Transtensive relays and pull-apart openings along N70 to N100 trending faults. NNW-SSE tension gashes filled by $\mathrm{Pb}-\mathrm{Ba}$ mineralizations and hosted by: Bajocian limestones (h) and Middle Liassic dolomitic limestones (i). 


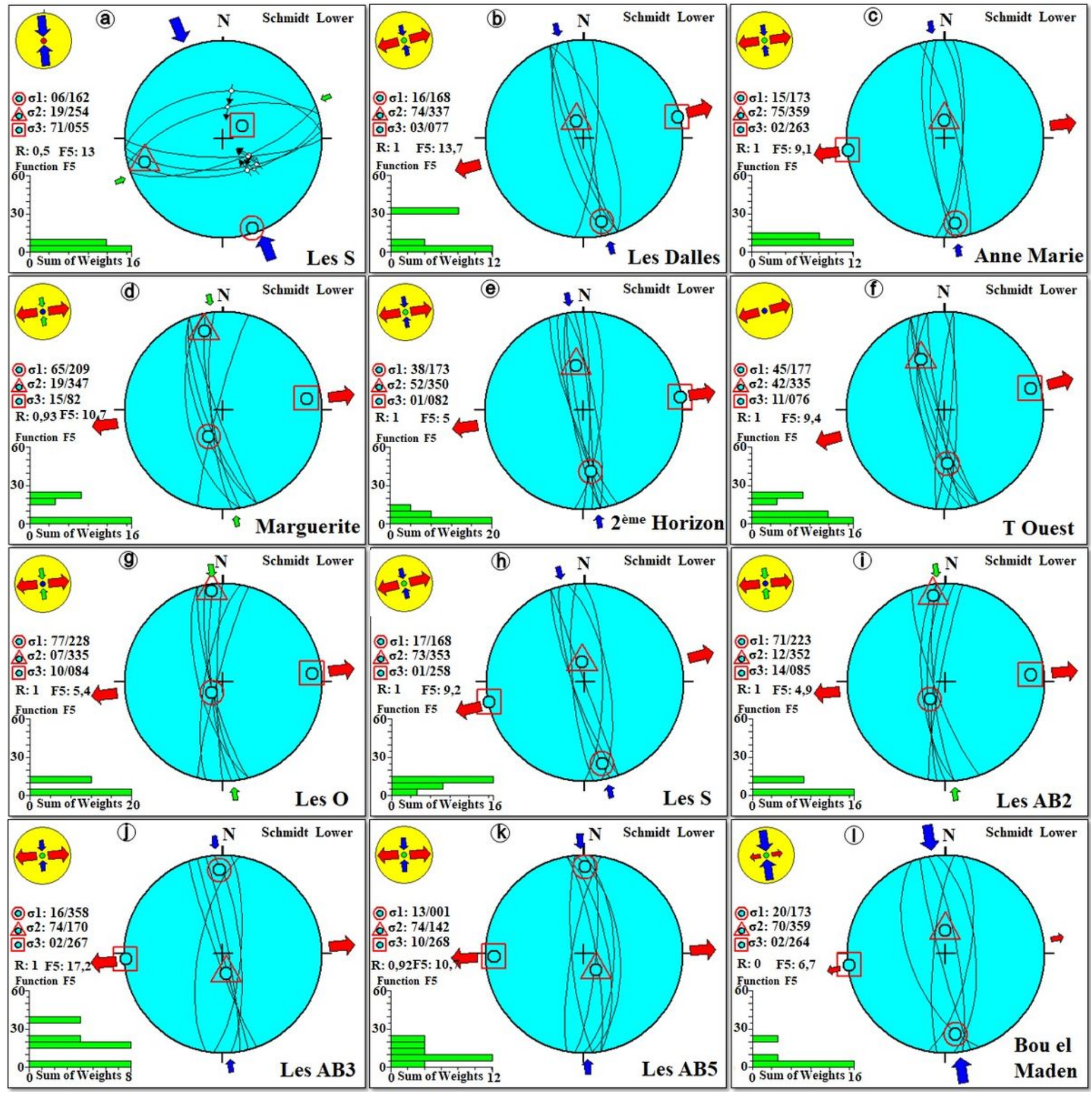

Figure 10

Results of the reconstruction of stress fields responsible for $\mathrm{Pb}$-Ba mineralizations emplacement in the Mibladen ore deposit. a) Corresponding stereoplot of mineralized reverse faults. b to I) Corresponding stereoplots of mineralized tension gashes. Stereograms (equal-area stereographic projection) with traces of fault planes and tension gashes, observed slip lines and slip senses, ratio $\mathrm{R}$ value, distribution histogram of the misfit function F5, F5-misfit function, the principal stress axes $(\sigma 1, \sigma 2, \sigma 3)$ are reported. See measurement sites in Fig. 4. 


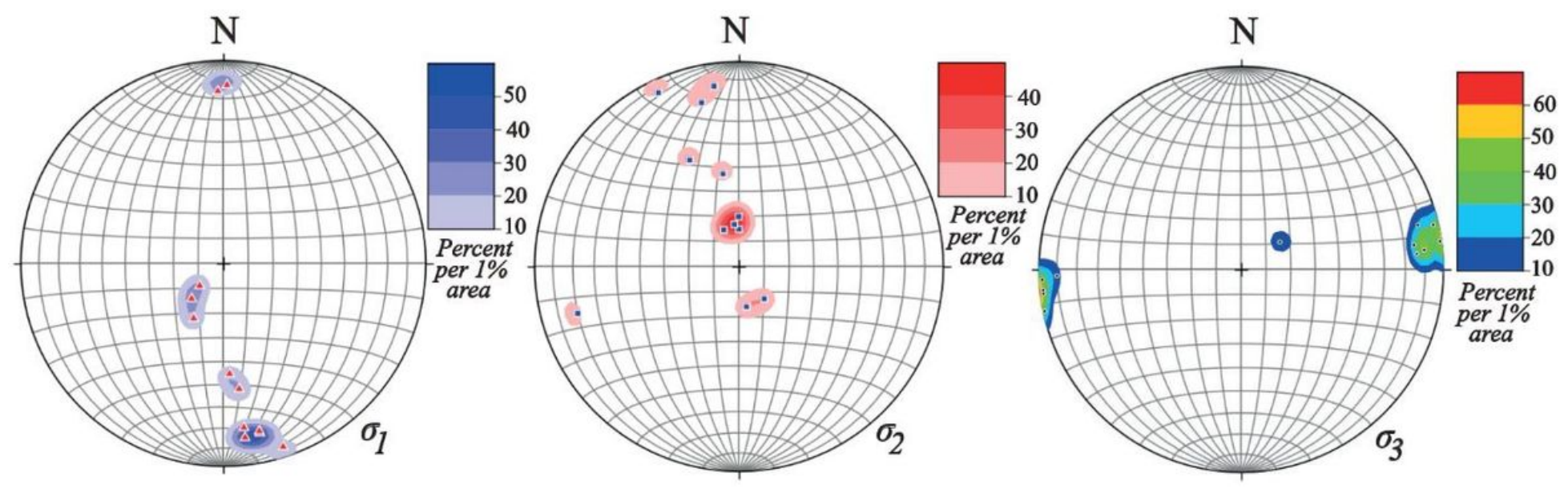

Figure 11

Statistical analyses of 01, 02 and o3 stress axes reported in Fig. 10 (equal-area stereographic projection, lower hemisphere).

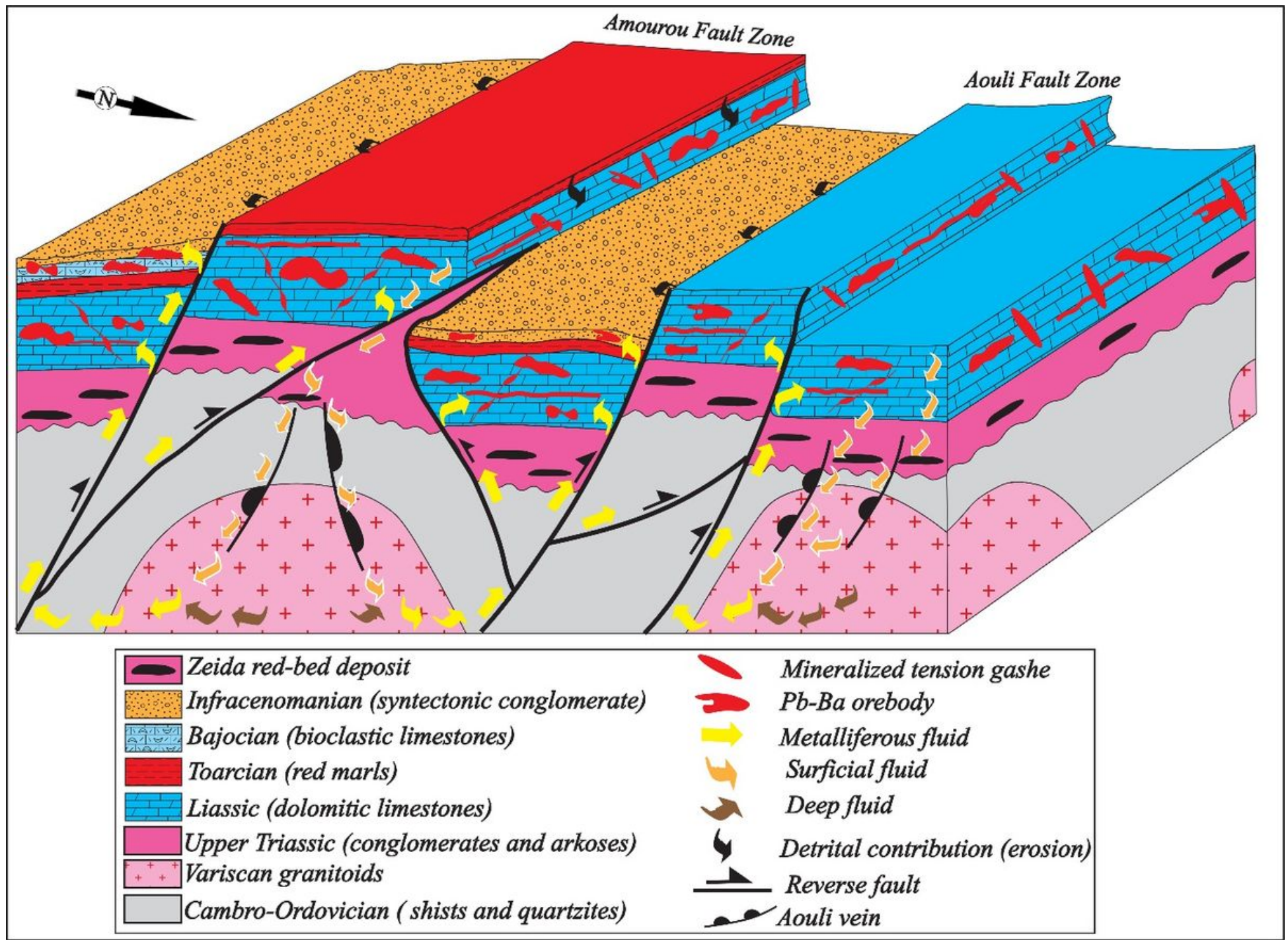

Figure 12 
Simplified schematic model for the Pb-Ba mineralization emplacement in the Mibladen ore deposit during the Infracenomanian period (Upper Jurassic-Early Cretaceous) (without scale). 